IOSR Journal of Pharmacy

ISSN: 2250-3013, www.iosrphr.org

||| Volume 2 Issue 5 ||| Sep-Oct. 2012 ||| PP.01-06

\title{
Accelerated stability study of herbal capsules
}

\author{
K.Bankoti, M.S Rana, M.K Bharadwaj* \\ Department of Pharmaceutical sciences, Bhimtal, Nainital; Uttrakhand. \\ *G.M Patanjali Ayurved Limited, Haridwar, Uttrakhand.
}

\begin{abstract}
Many drugs have been used for immuno-modulation and general weakness. From time immemorial herbs have been used due to advantage of Lesser or no side effects. Ashwagandha have been used from past for immuno-modulation and also as anti stress agent. Shilajeet is a unique blend of herbal and a mineral ingredient formed by unique natural process and is used as general tonic stimulant and aphrodisiac of authentic quality. In the present work stability profile of the herbal capsules (Ashwagandha, Shilajeet and Ashwashila) was analyzed. The change in quantifiable components was within $90 \%$ of the initial amount, indicating the stability of the product for more than 2 years at room temperature.
\end{abstract}

Keywords — accelerated stability study, herbal capsules, standardization

\section{INTRODUCTION}

India is sitting gold mine of well recorded and traditionally well practised knowledge of herbal medicines. The most important challenge faced by herbal formulations arises from lack of complete evaluation of its constituents, due to its complex nature. Evaluation of constituents is necessary to ensure quality, purity and stability of the herbal product. Stability study provides evidence on how quality of a drug substance or product varies with time under influence of variety of environmental factors such as, temperature, humidity and light and also to establish a retest period for the drug substance or product and recommended storage conditions. So we can say stability study is necessary as an assessment of product quality.

Pharmaceutical products are generally studied for stability profile at accelerated temperature and humidity, the experimental findings of which can be very helpful to predict reliable self life or expiry date at room temperature by adopting certain assumptions and criterions (Cannors et al.1979). . Every product has definite self-life which depends on various physical, chemical, environmental and biological factors. Real time study is a long procedure. The manufacturer finds it difficult to wait till the drug degrades naturally to $90 \%$ of its labelled amount at room temperature. On this account stability study is normally carried out for assigning selflife of the drugs.

Quality guidelines known as ICH guidelines have established a series of guidelines acceptable to multiple countries for the drug approval process. (ICH Guidelines)

It is a normal practice to study the stability of pharmaceutical preparations at accelerated conditions of temperature and humidity, the experimental findings which can be transformed into reliable shelf life or expiry date by adopting certain assumptions or criterions (Cannors et al.1979). By this method the shelf life of any drug product can be predicted in a very short period of time.

In comparison to conventional preparations herbal product represents number of unique problems when quality and stability are considered. To ensure proper reproducibility, proper control is essential, an important part of quality control is to ensure the chemical stability of final product during storage product. Present study is an attempt to study accelerated stability of herbal capsules, which are generally for immuno - modulation, these have been prepared using time tested herbal ingredient in optimum concentration which includes Withania Somnifera (Ahwagandha), (Shilajeet)

\section{MATERIAL AND METHOD}

The present work on "Accelerated Stability study of Herbal Capsules", was undertaken to standardize and study the stability profile of Herbal Capsules, namely Ashwagandha, Ashwashila and Shilajeet Capsules. The study was done at accelerated temperature and humidity conditions, i.e. accelerated stability study taking ICH guidelines as reference.

Blisters of ten capsules of Ashwagandha, Shilajeet and Ashwashila were randomly collected from Patanjali Ayurved Ltd Haridwar. Enough blisters in duplex were kept in humidity chamber at $40^{\circ} \pm 2^{\circ} \mathrm{c}$ and $70 \pm$ $5 \%$ humidity, and in room temperature at $37 \pm 2^{\circ} \mathrm{c}$ and normal humidity. Required blisters were withdrawn after one, two, three and six month in triplicate for analysis. The main ingredient of Ashwagandha capsule was 
ashwagandha extract, Shilajeet capsule contained Shilajeet extract and that of Ashwashila capsule had both Ashwashila and shilajeet extract. For evaluation different parameters were taken that were organoleptic evaluation, identification test (through HPTLC), Average weight content, locking length, disintegration test, $\mathrm{pH}$

( $1 \%$ solution), total ash, acid insoluble ash, assay for fulvic acid, withanolides and alkaloids, and Microbial limit test. Samples were tested at the time of their release of batch and after $1^{\text {st }}, 2^{\text {nd }}, 3^{\text {rd }}$ and $6^{\text {th }}$ month of storage.

Physical test like Average weight, uniformity of content, Loss on drying, $\mathrm{pH}$, ash value (total ash and acid insoluble) and disintegration test was performed according to IP 2007. Total alkaloids, Withanolides, fulvic acid were estimated according protocol given in Standardization of Botanicals testing and Extraction method of Medicinal herbs (Rajpal. V., 2005. ).

Heavy metal analysis was done by ICP OES by in house method. Sample preparation was done by digesting total ash of sample with $5 \%$ nitric acid and then using $5 \%$ nitric acid as blank, and standards of arsenic, lead, mercury and cadmium ICP OES was run and results were observed and noted.

HPTLC fingerprinting of finished product was done by in house method for fingerprinting of active constituents of the herbal capsules. Precoated aluminium plates with Silica Gel 60F254 (E. Merck, India) of 10 $\mathrm{x} 10 \mathrm{~cm}$ and $0.2 \mathrm{~mm}$ thickness, were used for the detection.

Sample preparation :Accurately weighed 1-2 g of extract and finished product equivalent to 1-2 $\mathrm{g}$ of extract were taken in separate iodine flask. Then $50 \mathrm{ml}$ methanol was added into each flask and refluxed for 1 hour. Filter the solution. Then the filtrate was concentrated to 1-2 ml. This solution was used for HPTLC fingerprinting. Different concentration of extract and finished product solution viz. 5 and $10 \mu \mathrm{l}$ was taken.

Standard preparation : Accurately weighed $0.5 \mathrm{gm}$. standard in an iodine flask and add $25 \mathrm{ml}$ methanol and reflux for half an hour. Filter the solution. Then the filtrate was concentrated to 1-2 ml. This solution was used for HPTLC finger-printing. (In house preparation)

Mobile phase:

Chloroform: Methanol (9:1) \{for Ashwagandha\}

Butanol : Acetic acid : Water (5:5:1) \{Shilajeet\}

Butanol : Acetic acid : Water (5:5:1) \{Ashvashila\}

Method:

$5.0 \mu \mathrm{l}$ of the standard solution and $5.0 \mu \mathrm{l}$ of each sample solution were applied with the help of CAMAG Linomat 5; applicator, as bands on the TLC plates. The plate was developed with mobile phase up to $8 \mathrm{~cm}$. The developed chromo- plate was dried by hair dryer. The plate was sprayed with spraying reagent, and dried in hot air oven at $105^{\circ} \mathrm{C}$ for 5 to 10 minutes. Then the plate was photo documented and $\mathrm{R}_{\mathrm{f}}$ value was calculated.

Microbiological limit test was done according to Hand book of microbial quality control.(Baired, et al. 2000))

\section{RESULT AND DISCUSSION}

The physical parameters of initial sample and sample analysed after 1, 2, 3 and $6^{\text {th }}$ month of storage at accelerated conditions of temperature and humidity are found to be similar, indicating that there gross physical characteristics does not produce any significant change, observation have been tabulated below for all three herbal capsule. The similar results are observed in the assay of active principles of capsules when analyzed initially and at regular interval of time (i.e. $1^{\text {st }}, 2^{\text {nd }}, 3^{\text {rd }}$ and $6^{\text {th }}$ month) Result of both physical and chemical analysis were found under limit as observed in tables $2,3 \& 4$. On comparing HPTLC fingerprinting of standard, initial as well as sample stored at accelerated conditions of temperature and humidity it was concluded that the samples contain their respective active principle HPTLC graphs are documented in figure $1,2 \& 3$. Results of Microbiological limit test were also under limit and didn't showed any significant change.

\begin{tabular}{|l|l|}
\hline $\begin{array}{l}\text { Shelf life } \\
\text { (in years) }\end{array}$ & $\begin{array}{l}\text { Time } \\
\text { (in months) }\end{array}$ \\
\hline 2 & 2.9 \\
\hline 3 & 5.2 \\
\hline 4 & 6.1 \\
\hline 5 & 9 \\
\hline
\end{tabular}

Table: 1 
Table 2. Results of different parameters used for accelerated stability study test for ashwagandha capsule

\begin{tabular}{|c|c|c|c|c|c|c|c|}
\hline S.N.O & PARAMETERS & LIMITS & $\begin{array}{c}\text { ANALYSIS } \\
\text { AT } \\
\text { RELEASE }\end{array}$ & $\begin{array}{c}1^{\text {st }} \\
\text { Month }\end{array}$ & $\begin{array}{c}2^{\text {nd }} \\
\text { Month }\end{array}$ & $\begin{array}{c}3^{\text {rd }} \\
\text { Month }\end{array}$ & $\begin{array}{c}6^{\text {th }} \\
\text { Month }\end{array}$ \\
\hline 1. & Description & $\begin{array}{l}\text { Green smooth } \\
\text { vegi - capsule } \\
\text { with dark brown, } \\
\text { fluffy powder } \\
\text { along with } \\
\text { characteristic } \\
\text { odour and } \\
\text { astringent taste. }\end{array}$ & Complies & Complies & Complies & Complies & Complies \\
\hline 2. & Identification & $\begin{array}{l}\text { H.P.T.L.C, } \\
\text { match with } \\
\text { standard }\end{array}$ & Complies & Complies & Complies & Complies & Complies \\
\hline 2. & $\begin{array}{l}\text { Average } \\
\text { weight }(\mathrm{mg})\end{array}$ & $550 \pm 5 \%$ & 557.73 & 559.14 & 558.21 & 557.93 & 558.25 \\
\hline 3. & Locking length & $20-21 \mathrm{~mm}$ & 20.83 & 20.86 & 20.84 & 20.85 & 20.85 \\
\hline 4. & Disintegration & NMT - 30min. & 12.32 & 12.40 & 12.39 & 12.41 & 12.34 \\
\hline 5. & $\mathrm{pH}$ (1\% solution) & $5.00-7.00$ & 5.18 & 5.18 & 5.20 & 5.20 & 5.20 \\
\hline 6. & Total Ash (\%w/w) & $<30$ & 10.97 & 10.98 & 11.01 & 10.99 & 11.04 \\
\hline 7. & $\begin{array}{l}\text { Acid Insoluble Ash } \\
(\% \mathrm{w} / \mathrm{w})\end{array}$ & $<3$ & 2.1248 & 2.1359 & 2.1341 & 2.1345 & 2.1345 \\
\hline 8. & $\begin{array}{l}\text { Assay of } \\
\text { (Alkaloids) }(\% \mathrm{w} / \mathrm{w})\end{array}$ & $>1.0$ & 1.3182 & 1.3800 & 1.3742 & 1.4123 & 1.3256 \\
\hline 9. & $\begin{array}{l}\text { Assay of } \\
\text { withanolides }\end{array}$ & $>2.5$ & 2.7612 & 2.8122 & 2.81343 & 2.6978 & 2.7864 \\
\hline
\end{tabular}

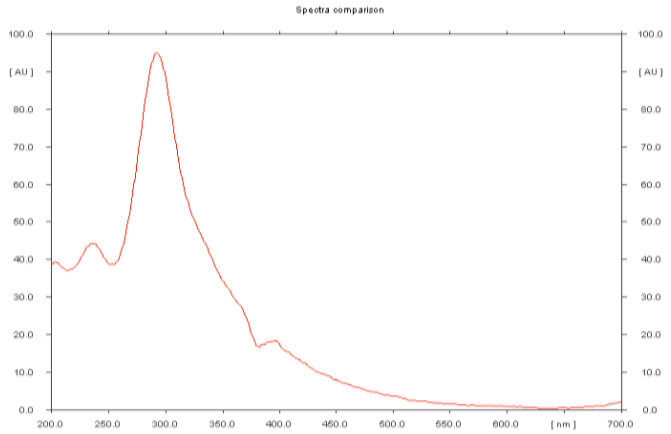

Spectra of Std.

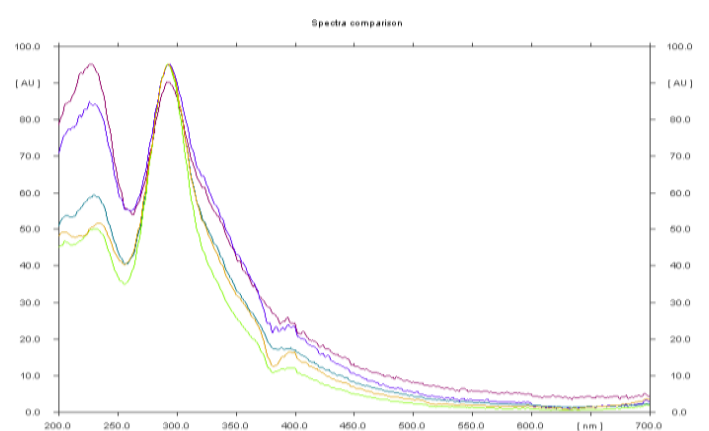

Spectra of Std. \& Sample

HPTLC fingerprinting of Ashwagandha Capsule 
Table 3: Results of different parameters used for accelerated stability study test for Shilajeet Capsule

\begin{tabular}{|c|c|c|c|c|c|c|c|}
\hline S.N.O & PARAMETERS & LIMITS & $\begin{array}{c}\text { ANALYSIS } \\
\text { AT } \\
\text { RELEASE }\end{array}$ & $\begin{array}{c}1^{\text {st }} \\
\text { MONTH }\end{array}$ & $\begin{array}{c}2^{\text {nd }} \\
\text { MONTH }\end{array}$ & $\begin{array}{c}3^{\text {rd }} \\
\text { MONTH }\end{array}$ & $\begin{array}{c}6^{\text {th }} \\
\text { MONTH }\end{array}$ \\
\hline 1. & Description & $\begin{array}{l}\text { Green smooth } \\
\text { vegi - capsule } \\
\text { with dark } \\
\text { brown, fluffy } \\
\text { powder along } \\
\text { with } \\
\text { characteristic } \\
\text { odour and } \\
\text { astringent taste. }\end{array}$ & Complies & Complies & Complies & Complies & Complies \\
\hline 2. & Identification & $\begin{array}{l}\text { H.P.T.L.C, } \\
\text { match with } \\
\text { standard }\end{array}$ & Complies & Complies & Complies & Complies & Complies \\
\hline 3. & $\begin{array}{l}\text { Average weight } \\
(\mathrm{mg})\end{array}$ & $550 \pm 5 \%$ & 523.71 & 524.14 & 524.11 & 523.98 & 523.96 \\
\hline 4. & Locking length & $21-22 \mathrm{~mm}$ & 21.067 & 21.072 & 21.068 & 21.067 & 21.067 \\
\hline 5. & Disintegration & NMT - 30min. & 9.01 & 10.04 & 9.07 & 9.06 & 9.06 \\
\hline 6. & $\mathrm{pH}(1 \%$ solution $)$ & $5.00-7.00$ & 6.03 & 5.88 & 5.93 & 5.79 & 5.98 \\
\hline 7. & $\begin{array}{l}\text { Total Ash } \\
(\% \mathrm{w} / \mathrm{w})\end{array}$ & $<30$ & 21.9287 & 20.9710 & 21.8954 & 20.9811 & 21.8623 \\
\hline 8. & $\begin{array}{l}\text { Acid Insoluble } \\
\text { Ash) }\end{array}$ & $<5$ & 4.6619 & 4.8971 & 4.9321 & 4.7834 & 4.9632 \\
\hline 9. & $\begin{array}{l}\text { Assay of Fulvic } \\
\text { acid }(\% \mathrm{w} / \mathrm{w})\end{array}$ & $>1.0$ & 2.3156 & 2.3023 & 2.2834 & 2.2765 & 2.2822 \\
\hline
\end{tabular}

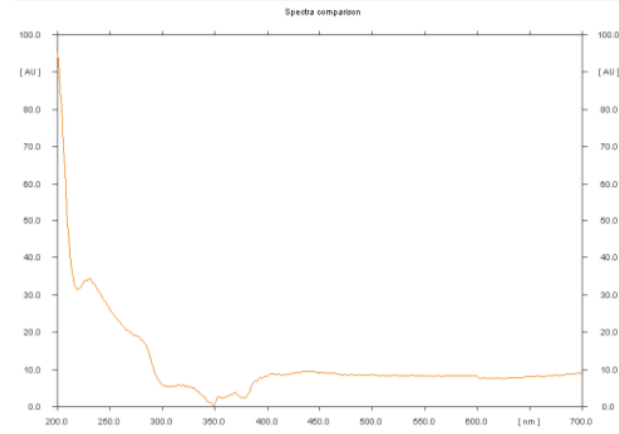

Spectra of Std.

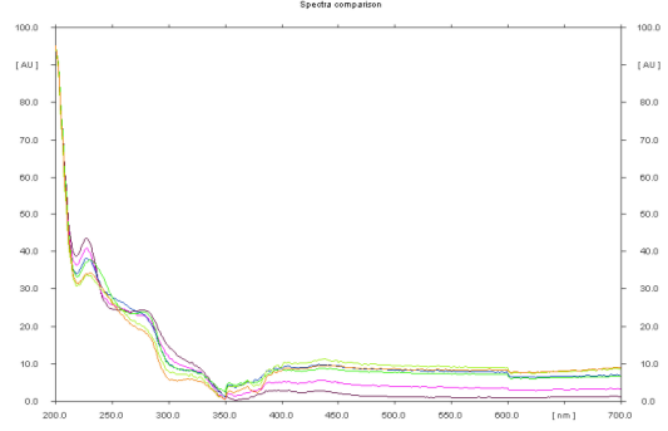

Spectra of Std. \& Sample

Figure 2: HPTLC fingerprinting of Shilajeet Capsule 
Table 4: Results of different parameters used for accelerated stability study test of Ashwashila capsule

\begin{tabular}{|c|c|c|c|c|c|c|c|}
\hline S.N.O & PARAMETERS & LIMITS & $\begin{array}{l}\text { ANALYSIS } \\
\text { AT } \\
\text { RELEASE }\end{array}$ & $\begin{array}{l}1^{\text {st }} \\
\text { MONTH }\end{array}$ & $\begin{array}{l}2^{\text {nd }} \\
\text { MONTH }\end{array}$ & $\begin{array}{l}3^{\text {rd }} \\
\text { MONTH }\end{array}$ & $\begin{array}{l}6^{\text {th }} \\
\text { MONTH }\end{array}$ \\
\hline 1. & Description & $\begin{array}{l}\text { Green } \\
\text { smooth vegi - } \\
\text { capsule with } \\
\text { dark brown, } \\
\text { fluffy powder } \\
\text { along with } \\
\text { characteristic } \\
\text { odour and } \\
\text { astringent } \\
\text { taste. }\end{array}$ & Complies & Complies & Complies & Complies & Complies \\
\hline 2. & Identification & $\begin{array}{l}\text { H.P.T.L.C, } \\
\text { match with } \\
\text { standard }\end{array}$ & Complies & Complies & Complies & Complies & Complies \\
\hline 3. & $\begin{array}{l}\text { Average } \\
\text { weight }(\mathrm{mg})\end{array}$ & $510 \pm 5 \%$ & 532.9 & 534.2 & 533.2 & 530.1 & 531.5 \\
\hline 4. & Locking length & $20-21 \mathrm{~mm}$ & 20.821 & 20.831 & 20.83 & 20.82 & 20.81 \\
\hline 5. & Disintegration & $\begin{array}{l}\text { NMT } \\
\text { 30min. }\end{array}$ & 12.11 & 12.50 & 12.38 & 12.49 & 12.44 \\
\hline 6. & $\mathrm{pH}$ (1\% solution) & $6.00-7.00$ & 6.14 & 6.18 & 6.17 & 6.19 & 6.17 \\
\hline 7. & 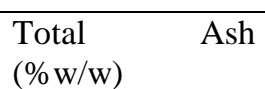 & $<18$ & 17.8539 & 17.7912 & 17.6818 & 17.5410 & 17.3421 \\
\hline 8. & $\begin{array}{l}\text { Acid Insoluble } \\
\text { Ash }(\% \mathrm{w} / \mathrm{w})\end{array}$ & $<3$ & 2.9771 & 2.9569. & 2.9412 & 2.8912 & 2.8211 \\
\hline 9. & $\begin{array}{ll}\text { Assay } & \text { of } \\
\text { (Alkaloids) } \\
(\% \mathrm{w} / \mathrm{w})\end{array}$ & $>0.5$ & 1.2451 & 1.22 & 1.28 & 1.23 & 1.27 \\
\hline 10. & $\begin{array}{l}\text { Assay of fulvic } \\
\text { acid }\end{array}$ & $>0.5$ & 2.3512 & 2.34 & 2.30 & 2.32 & 2.33 \\
\hline
\end{tabular}

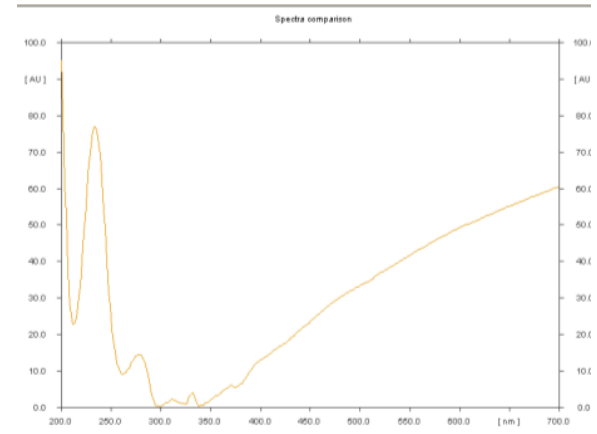

Spectra of Std.

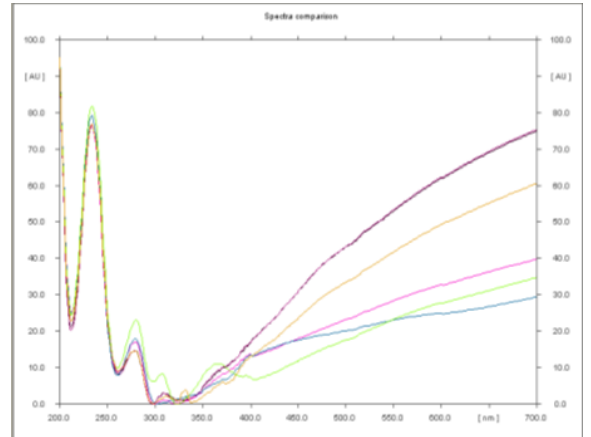

Spectra of Std. \& Sample

Figure 3: HPTLC fingerprinting of Ashwashila Capsule 
Above studies indicate these herbal capsules are stable at room temperature for more than 2 years. According to 'ICH Guidelines' 'Q1E', when data show little or no variation with time than statistical analysis are not required, and proposed shelf life is twice of real time data, but not more than $\mathrm{R}+12$ months (30 month maximum). Expiry of capsules is of two years, so from above study it can be concluded that the self- life of these herbal capsules can be extended to 12 months or more. However real time studies are underway to confirm these findings.

This approach will unquestionably build an innovative way for maintaining the quality, consistency, safety as well as stability of different herbal products. These efforts can ensure uniform therapeutic functionality and stability of different herbal products. Consequently, we can achieve an absolute globalization can be achieved through standardization and stability study of herbal medicines, helping Indian herbal market to achieve the international forum.

\section{REFERENCES}

[1]. Cannors, K.A., Amidon, G.L and Kennon, L., 1979. 'Chemical Stability of Pharmaceuticals'. A handbook of Pharmacists. John Wiley \& Sons, New York.

[2]. $\quad$ Baired, R.M., Hodge, N.A., Denyer, S.P.2000. Hand book of microbial quality control. p.22-36.

[3]. $\quad$ www.ICH.org - assessed on 21 november 2010.

[4]. Indian Pharmacopoeia., 2007. Government of India Ministry of health \& family welfare,

[5]. Published by The Indian Pharmacopoeia Commision., Ghaziabad, Page no. 78,

[6]. $134,182,177,178,42$.

[7]. Rajpal. V., 2005. Standardization of Botanicals. Testing and Extraction method of Medicinal herbs. $1^{\text {st }}$ ed. Delhi: eastern publisher;. (1, 2): 88, 283.

[8]. World Health Organization - 2004. Health Administrator vol : XX, Number 1

[9]. \& 2:120-121Pg.30 Quality Assurance Of Herbal Medicinal Products.

[10]. Upadhyay, K. Avinash., Kumar, Kausal and Mishra, Harishankar., 2009. "Effects

[11]. of combination of Shilajit (Asphaltum punjabianum) and Ashwagandha (Withania somnifera) on fasting blood sugar and lipid profile". Journal Of Pharmacy Research 2009, 2(5). US Dietary Supplement Health and Education Act of 1994. 